of certificates cannot be inflicted upon him, and the necessity for new contracts becomes all the more imperative, in order that the Act may be properly carried out.

And now with regard to the question of fees payable under the new Act. And, first, we will refer to the fees payable uder contracts. It is made a sine quấ non that for a claim to be legally made, on the one hand, and paid, on the other, the vaccinator must not only have been appointed by the guardians to perform the vaccination of their district, but must also have had his contract approved by the Poor-law Board. And the Act is very emphatic on this point; for it enacts that " no payment in respect of vaccination shall be made out of the common fund of any union, or out of the poor-rate of any parish, or out of any other public or parochial fund where the Poor-law Board shall not have approved of a contract for the performance thereof." And, in order that there shall be no mistake on this point, the Act further directs that every payment made contrary to this provision "shall be disallowed by the auditor." This prohibition of payment also extends to "cases where the Poor-law Board shall have determined con. tracts, a power which has been given to the Board by the 9th section of the Act.

It must next be borne in mind that the amount of the fees themselves is a matter entirely between each contractor and his board of guardians. The Legislature has not placed any limit on their largeness ; but, as a slight protection of the in. terests of the vaccinators, whom most guardians have but too readily evinced a desire to grind down to the lowest possible amount, the Legislature has placed a minimum limit, below - which no board of guardians can go. The minimum scale, under the new Act, is considerably better than that under the old Act, as will be seen by comparing as follows:-

Under the old Act the fees were-

For every person vaccinated at the residence of the contractor, or within two miles therefrom, by the nearest public road, not less than 1s.6d. Beyond the above. - named distance not less than $2 s .6 d$.

Under the new Act the fees are

For every vaccination done at an appointed station, situated at or within one mile from the residence of the vaccinator, or in the workhouse, not less than $1 s .6 d$; for every vaccination done at a station over one mile and under two miles distant from-the residence of the vaccinator, not less than 2s. 6d.; and at any station which is more 'than two miles distant from the vaccinator's residence, $3 s$. For vaccinations performed elsewhere than at a station or in a workhouse-or, in other words, for domiciliary vaccinations-according to the terms specified in the contract.

It will thus be seen that, as we have said above, the scale under the Act of 1867 is much more liberal than the scale under the Act of 1853. In order, however, to obtain the increased fees it is absolutely necessary that the practitioner should enter into a contract under the new Act of 1867 . But there is no necessity for the fees being kept even at so low a standard as the minimum limit fixed by the new Act. We have said on former occasions that if the whole of the profession would agree as to the amount which should be paid for each operation, this important matter of vaccination fees might, we think, soon be placed on a footing more satisfactory to that large class of prac. titioners who are interested in this particular branch of the Poor-law medical service.

Thus far we have spoken of contractors who are district vaccinators, but we must also devote a small space to the other class of contractors - namely, workhouse vaccinators. From a correspondence which appeared in our columns on the 26th September last, it will be seen that the Poor-law Board hold that unless a workhouse medical officer has a contract entered into since the Act of 1867 came into operation, which contract " shall contain special provision for payment in respect of the performance of vaccination in workhouses at the rate of remuneration prescribed by sect. 6 of the Vaccination Act of 1867 , he will not be entitled to any fee in respect of cases of success. ful vaccination performed by him in the workhouse." And that such is the case is quite clear, for, as we have already atated; the Act directs that none but contractors shall be paid any fee out of the parochial funds on account of vaccinations performed.
We may take this opportunity of reminding those of our brethren who hold vaccination contracts under the Act of 1853 , that they can secure the advantages of the new Act by giving twenty-eight days' notice in writing to their respective boards of guardians of their intention to terminate their contracts, provided, of course, that they can rely upon their being reappointed to the offices which they, of their own free will, vacate. And we advise all workhouse medical officers at once to request their respective boards of guardians to enter into contracts with them for the performance of public vaccination, otherwise they will not be entitled to the fee which Parliament has directed shall be paid to them, and so- one of the benefits of the Act will be lost to those for whom it was intended.

And here we propose to pause; intending to resume, next week, our consideration of this important matter. Our next notice will deal with those provisions of the Act which relate to the certificates to be given by medical $m \in n$, and to the transmissinn of such of them as the Act direets'to-be'sent to' the registrars.

\section{PROPOSED NEW INFIRMARY AT OLDHAM.}

\section{To the Editor of THE LANCET.}

SrR, - The town of Oldham, distant about six miles from Manchester, though virtually a suburb of that city, contains a population of about 90,000 . It has hitherto been without a charitable medical institution of any description. Its numerous workshops and cotton factories have supplied a fertile field for the treatment of acute surgical cases, and these, with the exception of a comparatively small number sent to the "Manchester Infirmary, have been treated, through the liberality of the employers of labour, as private patients at their own homes. The comfortable circumstances and, as a rule, the excellent condition of the dwellings of the working population, have $\mathrm{tr}$ abled this to be done, not only without disadyantage, but, 1 am persuaded, from the favourable result almost uniformly seen after capital operations, with positive benefit to those ur. fortunate enough to suffer accidents by machinery.*

Now, however, infected by the movement in Wigan, Blackburn, and other towns, it is intended to build an intirmary and dispensary for the reception and treatment of these and other cases. The Mansion-house Committee, out of the surplus fund subscribed some years ago for the relief of the operatives during the cotton famine, have apportioned to Oldham, under an order of the Court of Chancery, $£ 1000$; and, with this as a nucleus, it is proposed to raise $£ 9000$ additional for the above purpose.

$I$, in common with my professional brethren here, hold a firm conviction, formed after some experience in other places, that of all the charitable institutions in the country none are more liable to abuse than those to which the medical profession are called upon to minister. The debates in the Social Science Congress at Birmingham a few weeks'ago sufficiently attest this. We are therefore desirous, whilst the institution here is in a nascent state, to use our influence for the purpose of correcting or mitigating some of the evils most grievously complained of-evils tending to the demoralisation of the working classes themselves, and certainly most injurious to the interests of the junior members of our profession.

It ncours to me that this may, perhaps, be best attained by insisting on the adoption of such measures, whether by a paid. officer or otherwise, as may be necessary for the rigid exclusion of all but the necessitous; and by advocating payment for the services of the medical staff, on the ground, irrespective of the question of bare justice, that, from our proximity to a large county bospital, no status will be conferred on those holding its appointments.

In my opinion, the profession in this country ought long ago to have resisted the burdens imposed upon it by the public. Want of union amongst ourselves is undoubtedly the one potent reason why year after year these burdens have gone on accumulating, until they have at last culminated in the recent disgraceful Vaccination Act.

If any of your numerous readers, either privately or through your columns, feel disposed to assist by 'their suggestions' in placing matters on a better footing in this town, he will confer a benefit on the profession generally.

I am, Sir, your obedient servant,

Dirham, Nnv. 3 d, 1868

A. Тном Тномsox.

* I hupe to pat on record at some future time the result of operations performed under such circnmstances; with the view ot comptoison with tłat obtaining in large hospitals. 